\title{
The level of anxiety and depression in patients admitted to an infertility clinic
}

\section{Bir infertilite kliniğine başvuran hastalarda anksiyete ve depresyon düzeyleri}

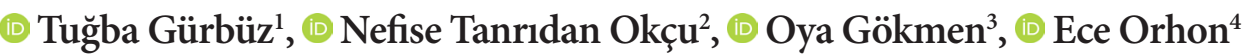 \\ ${ }^{1}$ Medistate Hospital, Gynecology and Obstetric Clinic, İstanbul, Turkey \\ ${ }^{2}$ Adana City Training and Research Hospital Obstetrics and Gynecology Clinic, Adana, Turkey \\ ${ }^{3}$ Medistate Hospital, Gynecology and IVF Clinic, İstanbul, Turkey \\ ${ }^{4}$ Acıbadem Kadıköy Hospital, Physchiatry Clinic, İstanbul, Turkey
}

Cite this article as / Bu makaleye atıf için: Gürbüz T, Tanrıdan Okçu N, Gökmen O, Orhon E. The level of anxiety and depression in patients admitted to an infertility clinic. J Health Sci Med 2020; 3(3): 240-244.

\begin{abstract}
Aim: Infertility affects women biologically, psychologically and socially and as a result, it decreases the quality of life. The aim of this study was to investigate the effect of infertility on anxiety and depression in women.

Material and Method: The study was planned as an observational study. Patients who were diagnosed as infertile and were admitted to Medistate Hospital Obstetrics, In Vitro Fertilization outpatient clinic, Adana City Training and Research Hospital, and Obstetrics and Gynecology outpatient clinic between May and November 2019 were included in the study. The inclusion criteria were the patients who had been diagnosed as infertility for at least one year. A questionnaire including 'Beck Anxiety Inventory' and "Beck Depression Inventory" was completed with the face-to-face interview technique by volunteer infertile women who met the inclusion criteria.

Results: The study was completed with 200 volunteer infertile patients. According to the depression score, 60 (30\%) of the participants were normal, $84(42 \%)$ had mild, 40 (20\%) had moderate and $16(8 \%)$ had severe depression. According to the anxiety score, $72(36 \%)$ of the participants were normal, 78 (39\%) had mild, 32 (16\%) had moderate and 18 (9\%) had severe anxiety.

Conclusion: Increased depression and anxiety scores should be considered in infertile patients. Further studies are needed to indicate which type of psychological treatment is more effective at the individual level.
\end{abstract}

Keywords: Infertility, depression, anxiety, psychological treatment

ÖZ

Amaç: İnfertilite kadını biyolojik, psikolojik ve sosyal açıdan olumsuz etkileyen ve sonuç olarak yaşam kalitesini düşüren bir durumdur. Bu çalışma ile infertilitenin kadınlarda anksiyete ve depresyon gelişmesi üzerine etkisinin araştırılması amaçlanmıştır.

Gereç ve Yöntem: Çalışma gözlemsel çalışma olarak planlandı. Çalışmaya Özel Medistate Hastanesi Kadın Hastalıkları ve Tüp Bebek Polikliniğine ve Adana Şehir Eğitim ve Araştırma Hastanesi Kadın Hastalıkları ve Doğum Polikliniği’ne Mayıs-Kasım 2019 arasında başvuran, infertilite tanısı alan hastalar dahil edildi. Çalışmaya dahil edilme kriterleri en az bir yıldır çocuk sahibi olmak isteyen ve infertilite tanısı almış hastalar olarak belirlendi. Çalışmaya alınma kriterlerine uygun gönüllü infertil kadınlar tarafından yüz yüze görüşme tekniği ile “Beck Anksiyete Ölçeği” ve "Beck Depresyon Envanteri” içeren anket formu dolduruldu.

Bulgular: Çalışma 200 gönüllü infertil hasta ile tamamlandı. Depresyon skorlarına göre 60 (\%30) hastanın skoru normal aralıkta, 84 (\%42) hastanın hafif, 40 (\%20) hastanın orta seviyede ve 16 (\%8) hastanın ciddi depresyonu mevcuttu. Anksiyete skorlarına göre 72 (36\%) hastanın skoru normal aralıkta, 78 (\%39) hastanın hafif, 32 (\%16) hastanın orta ve 18 (\%9) hastanın şiddetli anksiyetesi mevcuttu.

Sonuç: İnfertil hastalarda artan depresyon ve anksiyete skorlarına dikkat edilmelidir. Bireysel seviyede hangi psikolojik tedavi tipinin daha etkili olduğunu bildiren çalışmalara ihtiyaç duyulmaktadır.

Anahtar Kelimeler: İnfertilite, depresyon, anksiyete, psikoterapi 


\section{INTRODUCTION}

Infertility is defined as the absence of pregnancy despite 1 year of unprotected intercourse. The prevalence of infertility was found by about $8.1 \%$ in the study done in Turkey (1). The inability to have children adversely affects couples worldwide. Infertility affects women biologically, psychologically and socially and as a result, it decreases the quality of life (2). The studies show that infertile couples experience some psychological disorders such as lack of sexual satisfaction, lack of marital satisfaction, impaired relationships particularly between couples, lack of loss of confidence about sex and sexual intercourse, anger, negative emotional effects, etc. (3-6).

Therefore, it is discussed that infertile couples should be provided with appropriate counseling services by healthcare professionals to keep the biopsychosocial health in the diagnosis and treatment process. Early diagnosis and the evaluation of depression in infertile patients is important both for the success of the treatment and for the health of the patient (7). The aim of this study was to investigate the effect of infertility on anxiety and depression among the infertile women.

\section{MATERIAL AND METHOD}

The study was planned as an observational study. Patients who were diagnosed as infertile and were admitted to Medistate Hospital Obstetrics and In Vitro Fertilization (IVF) outpatient clinic and Adana City Training and Research Hospital Obstetrics and Gynecology outpatient clinic between May and November 2019 were included in the study. This study was approved by the university/local human research ethics committee and all procedures performed in studies involving human participants were in accordance with the ethical standards of the institutional and/or national research committee and with the 1964 Helsinki Declaration and its later amendments or comparable ethical standards. The study was carried out with the permission of Research Ethics Committee of Beykoz University (Permission granted / CAAE number: 2019/30.9, Decision no: 2).

All patients were selected randomly. The inclusion criteria included the patients who had been diagnosed as infertility for at least one year. The exclusion criteria included smoking, thyroid disease, diabetes mellitus, hypertension, and the patients with comorbidities. A questionnaire including 'Beck Anxiety Inventory (BAI)' and "Beck Depression Inventory (BDI)" was completed through face-to-face interview technique by volunteer infertile women who met the inclusion criteria.

\section{Beck Depression Inventory}

The BDI scale includes 21 items. The total score ranges from 0 to 63 points. It is used to evaluate the severity of depression in clinical use. 0-10 points indicate no depression, 11-17 points indicate mild depression, 18-29 points indicate moderate depression and 30-63 points indicate severe depression. BDI Turkish validity and reliability study was conducted by Hisli in 1988 with Cronbach Alfa internal consistency values of 0.74 (8).

\section{Beck Anxiety Inventory}

The BAI is a clinical scale containing 21 items. It was developed by Beck, Epstein, Brown, and Steer in 1988 to measure anxiety levels (9). The total score ranges from 0 to 63 points. BAI Turkish validity and reliability study was conducted by Ulusoy et al. (10) in 1993 with Cronbach Alfa internal consistency values of 0.81. BAI: 0-7 minimal 8-17 points indicate mild level, 18-24 points indicates a moderate level, and above 25 indicates severe anxiety.

\section{Statistical Analysis}

SPSS statistical package program for Windows (Statistical Package for Social Sciences, version 16.0, SPSS Inc. Chicago, Illinois, USA) was used to evaluate the study results. Percent and average calculations in descriptive statistics, chi-square analysis of the relationship between dependent and independent variables, Student $t$ and Mann-Whitney U test, One Way Analysis of Variance (One Way ANOVA), Pearson correlation analysis and multiple regression analysis methods were used. $\mathrm{p}<0.05$ was considered statistically significant.

\section{RESULTS}

Four-hundred patients were diagnosed with infertility at the Medistate Hospital Gynecology and IVF outpatient clinic and Adana City Training and Research Hospital Gynecology and Obstetrics outpatient clinic between May and November 2019. 150 patients were excluded due to smoking and 40 patients were excluded due to additional systemic disease. Ten infertile patients did not want to participate in the study. The study was completed with 200 volunteer infertile patients.

Fifty-four (27\%) of the participants were 29 years old below, 78 (39\%) were between 30 and 35 years and 68 (34\%) were 36 years above. According to body mass index, $74(37 \%)$ of the participants were normal, 108 (54\%) were overweight and 18 (9\%) were obese (Table 1). 142 patients (71\%) had infertility between 1 and 3 years, 52 patients $(26 \%)$ had $3-5$ years and 6 patients $(3 \%)$ had infertility for 5 years above (Table 2). According to education level, 12 (6\%) of the participants had primary, $44(22 \%)$ had secondary, 74 (37\%) had high school and $70(35 \%)$ had university degrees. 


\begin{tabular}{|c|c|c|}
\hline Age (year) & Number (n) & Percentage (\%) \\
\hline$\leq 29$ & 54 & 27.0 \\
\hline $30-35$ & 78 & 39.0 \\
\hline$\geq 36$ & 68 & 34.0 \\
\hline \multicolumn{3}{|l|}{ BMI } \\
\hline $18.5-24.9$ & 74 & 37.0 \\
\hline $25-29.9$ & 108 & 54.0 \\
\hline $30-39.9$ & 18 & 9.0 \\
\hline
\end{tabular}

\begin{tabular}{|lcc|}
\hline \multicolumn{3}{|c|}{ Table 2. Distribution of Infertility Duration of Patients } \\
\hline Duration of Infertility & Number (n) & Percentage (\%) \\
\hline 1-3 year & 142 & 71.0 \\
3-5 year & 52 & 26.0 \\
5 years and up & 6 & 3.0 \\
\hline
\end{tabular}

Of the participants, 160 (80\%) had positive and 40 (20\%) had negative emotions for treatment, $14(7 \%)$ of the participants were positive and 186 (93\%) were negative to the idea of adoption.

According to the depression score, 60 (30\%) of the participants were normal, 84 (42\%) had mild, 40 (20\%) had moderate and $16(8 \%)$ had severe depression (Table $3)$. According to the anxiety score, $72(36 \%)$ of the participants were normal, 78 (39\%) had mild, $32(16 \%)$ had moderate and 18 (9\%) had severe anxiety (Table 4). A statistically significant relationship was found between the mood and anxiety scores of the patients during the treatment process $(\mathrm{p}<0.05)$ (Table 5). There was a statistically significant relationship between depression scores and anxiety scores $(\mathrm{p}<0.05)$ (Table 5).

\begin{tabular}{|lcc|}
\hline \multicolumn{3}{|l|}{ Table 3. Distribution of Beck Depression Inventory of Patients } \\
\hline Depression Score & Number (n) & Percentage (\%) \\
\hline 0-10 (normal) & 60 & 30.0 \\
11-17 (mild) & 84 & 42.0 \\
18-29 (moderate) & 40 & 20.0 \\
30-63 (severe) & 16 & 8.0 \\
\hline
\end{tabular}

\begin{tabular}{|lcc|}
\hline \multicolumn{3}{|l|}{ Table 4. Distribution of Beck Anxiety Inventory of patients } \\
\hline Anxiety Score & Number (n) & Percentage (\%) \\
\hline 0-7 (minimal) & 72 & 36.0 \\
8-17 (mild) & 78 & 39.0 \\
18-24 (moderate) & 32 & 16.0 \\
25-63 (severe) & 18 & 9.0 \\
\hline
\end{tabular}

\section{DISCUSSION}

In the present study, 200 infertile patients voluntarily participated. Our study shows that $42 \%$ of the patients admitted to our clinic due to infertility had mild depression level, $20 \%$ had moderate and $8 \%$ had severe depression level. Mild anxiety level has been found in $39 \%$ of the patients. Sixteen percent had moderate and 9\% had severe anxiety. There was also significant relationship between the mood and anxiety scores of the patients during the treatment process and significant relationship was found between depression scores and anxiety scores.

Infertility is found in approximately $10 \%$ of the community and most of these patients seek assisted reproductive technology (ART) for pregnancy (11). Pinar et al. (2) reported that the probability of depression and anxiety increased in patients with infertility. Pinar et al. (12) showed the infertile group had symptoms of anxiety and depression and that $35 \%$ of the infertile group had

\begin{tabular}{|c|c|c|c|c|c|c|c|c|c|c|}
\hline \multirow{2}{*}{ Age } & Correlation & 1.000 & -0.009 & $0.726^{*}$ & 0.137 & $0.223^{*}$ & 0.117 & -0.075 & 0.080 & 0.035 \\
\hline & $\mathrm{p}$ Value & . & 0.931 & 0.001 & 0.173 & 0.026 & 0.248 & 0.457 & 0.430 & 0.732 \\
\hline \multirow{2}{*}{ BMI } & Correlation & -0.009 & 1.000 & 0.047 & $0.270^{*}$ & 0.002 & 0.157 & $-0.224^{*}$ & 0.155 & $0.233^{*}$ \\
\hline & $\mathrm{p}$ Value & 0.931 & . & 0.645 & 0.007 & 0.982 & 0.119 & 0.025 & 0.125 & 0.020 \\
\hline \multirow{2}{*}{$\begin{array}{l}\text { Marriage } \\
\text { Period }\end{array}$} & Correlation & $0.726^{*}$ & 0.047 & 1.000 & 0.117 & 0.131 & 0.060 & -0.152 & 0.186 & 0.114 \\
\hline & $\mathrm{p}$ Value & 0.001 & 0.645 & . & 0.245 & 0.194 & 0.550 & 0.132 & 0.064 & 0.257 \\
\hline \multirow{2}{*}{$\begin{array}{l}\text { Duration of } \\
\text { Infertility }\end{array}$} & Correlation & 0.137 & $0.270^{\star}$ & 0.117 & 1.000 & -0.005 & 0.054 & -0.101 & 0.036 & 0.148 \\
\hline & $\mathrm{p}$ Value & 0.173 & 0.007 & 0.245 & . & 0.964 & 0.592 & 0.320 & 0.719 & 0.141 \\
\hline \multirow{2}{*}{$\begin{array}{l}\text { Education } \\
\text { Status }\end{array}$} & Correlation & $0.223^{*}$ & 0.002 & 0.131 & -0.005 & 1.000 & -0.008 & -0.077 & -0.134 & -0.035 \\
\hline & $\mathrm{p}$ Value & 0.026 & 0.982 & 0.194 & 0.964 & . & 0.935 & 0.444 & 0.183 & 0.732 \\
\hline \multirow{2}{*}{$\begin{array}{l}\text { Sense for } \\
\text { Treatment }\end{array}$} & Correlation & 0.117 & 0.157 & 0.060 & 0.054 & -0.008 & 1.000 & 0.039 & 0.190 & $0.221^{*}$ \\
\hline & $\mathrm{p}$ Value & 0.248 & 0.119 & 0.550 & 0.592 & 0.935 & . & 0.699 & 0.058 & 0.027 \\
\hline \multirow{2}{*}{$\begin{array}{l}\text { The idea of } \\
\text { Adoption }\end{array}$} & Correlation & -0.075 & $-0.224^{*}$ & -0.152 & -0.101 & -0.077 & 0.039 & 1.000 & -0.019 & -0.074 \\
\hline & $\mathrm{p}$ Value & 0.457 & 0.025 & 0.132 & 0.320 & 0.444 & 0.699 & & 0.852 & 0.464 \\
\hline \multirow{2}{*}{$\begin{array}{l}\text { Depression } \\
\text { Score }\end{array}$} & Correlation & 0.080 & 0.155 & 0.186 & 0.036 & -0.134 & 0.190 & -0.019 & 1.000 & $0.339^{*}$ \\
\hline & $\mathrm{p}$ Value & 0.430 & 0.125 & 0.064 & 0.719 & 0.183 & 0.058 & 0.852 & . & 0.001 \\
\hline \multirow{2}{*}{$\begin{array}{l}\text { Anxiety } \\
\text { Score }\end{array}$} & Correlation & 0.035 & $0.233^{*}$ & 0.114 & 0.148 & -0.035 & $0.221^{*}$ & -0.074 & $0.339^{*}$ & 1.000 \\
\hline & p Value & 0.732 & 0.020 & 0.257 & 0.141 & 0.732 & 0.027 & 0.464 & 0.001 & . \\
\hline
\end{tabular}


no symptoms of depression while $25 \%$ had a "mild" level of symptoms, and $40 \%$ showed a "medium" depression level. $62.5 \%$ of the infertile women had "mild" anxiety, while $25 \%$ had "medium" and $12.5 \%$ had "severe "anxiety. There was also positive correlation between anxiety and depression among the infertile women. In the study by Yassa et al. (13), anxiety rate was reported as $57.5 \%$ in infertile patients. In infertile patients, the prevalence of anxiety was reported to be $79 \%$ in a study conducted in Pakistan, and $69 \%$ in a Spain study $(14,15)$. In our study, the anxiety was found in $64 \%$ of the patients $(39 \%$ had mild, $16 \%$ had moderate and $9 \%$ had severe anxiety) in accordance with the literature.

In the study by Yassa et al. (13), the rate of depression in patients who underwent ART was reported as $42.5 \%$ and $70 \%$ in the study conducted in Pakistan $(14,15)$. In our study, the rate of depression in infertile patients was $70 \%$. The different results in these studies may be due to varying degrees of cultural separation and social pressure in different countries.

Since the pregnancy rate in a single ART cycle is approximately 25\%, many couples have negative cycles and continue treatment again (16). Psychosocial effects on patients increase as the duration of infertility diagnosis and treatment increases (17). In the current meta-analysis, it was found that depression and anxiety rates increased as a result of ART failure and depression decreased as a result of successful ART (18).

In meta-analyses conducted by Matthiesen et al. (19) (2011) and Purewall et al. (20) (2017), it was reported that high baseline depression and anxiety scores before ART treatment would have negative effects on pregnancy outcomes. Boivin et al. (21) (2011) stated that baseline anxiety and depression scores had no negative effect on ART results. Purewall et al. (22) (2018) reported that changes in anxiety and depression scores in the baseline and treatment process had no effect on ART results. In the current review and meta-analysis, the importance of psychosocial support in couples who have failed ART results was emphasized (23). The ESHRE Infertility Declaration recommended that infertility centers should provide psychosocial and emotional support for patients (24). In a recent randomized controlled trial, brief mindfulness intervention has been reported to reduce depression and improve sleep quality in infertile patients (25).

A study by Karaca et al. (26) showed that global average stress level of the participating women $(171.53 \pm 33.61)$ was higher than the standard average stress level (134.4 \pm 33.8$)$ indicating that that women under the study had infertility -related stress which is above the average stress level. This is not consistent with our study results.
Benli et al. (27) found no difference between fertile and infertile women in terms of depression and anxiety. Benli also found that the total scores of those who had a negative feeling about the treatment process in infertile women and those who thought it had a negative effect on the life of infertility, the total scores of depression and anxiety, and the total scores of depression among those who did not have support during the treatment process were found to be negatively high $(p<0,05)$ which is consistent with our study that found significant relationship between the mood and anxiety scores of the patients during the treatment process.

Unal et al. (12) found that women were more adversely affected by infertility with increase of their age, duration of desire to have a child and duration of marriage while our study showed that $68 \%$ of the infertile women had depression and $64 \%$ of the infertile women had anxiety.

Karlidere et al. (28) found that Turkish women under ICSI or IVF treatment had depressive symptoms without clinical depression, state anxiety within a normal range and high trait anxiety. Outcomes of the infertility treatment could be predicted by the severity of the depressive symptoms and trait anxiety levels among the infertile women while our study showed that $68 \%$ of the infertile women had depression ( $42 \%$ with mild depression level, $20 \%$ with moderate and $8 \%$ with severe depression level) and $64 \%$ of the infertile women had anxiety.

Gulseren et al. (29) found that the group of patients who had pregnancy after three months showed significantly decreased levels of anxiety and depression than the group of patients who did not achieve.

This study has some limitations. One of the limitations of the study is that it is not enough to have only depression and anxiety scale to determine the level. Normal healthy people also have depression and anxiety. The important thing is to see whether this is at the level of disorder. This is used in DSM or ICD. The use of DSM and ICD is a significant limitation. One of the other limitations of the study is that the scales have been applied by obstetrician not a psychologist or a psychiatrist.. One of the other limitations is that a healthy control group is absent in our study. However, the number of volunteers included in the study was appropriate for the assessment of depression and anxiety rates.

\section{CONCLUSION}

Increased depression and anxiety scores should be considered in infertile patients. In infertility clinics, patients should be evaluated by professionals in terms of their mental health status and appropriate psychological counseling should be provided. Further studies are needed that indicate which type of psychological treatment is more effective at the individual level. 


\section{ETHICAL DECLARATIONS}

Ethics Committee Approval: The study was carried out with the permission of Research Ethics Committee of Beykoz University (Permission granted /CAAE number: 2019/30.9, Decision no: 2).

Informed Consent: Written informed consent was obtained from all participants who participated in this study.

Referee Evaluation Process: Externally peer-reviewed.

Conflict of Interest Statement: The authors have no conflicts of interest to declare.

Financial Disclosure: The authors declared that this study has received no financial support.

Author Contributions: All of the authors declare that they have all participated in the design, execution, and analysis of the paper, and that they have approved the final version.

\section{REFERENCES}

1. Sarac M, Koc I. Prevalence and risk factors of infertility in turkey: evidence from demographic and health surveys, 1993-2013. J Biosoc Sci 2018; 50: 472-90.

2. Pinar G, Zeyneloglu HB. Quality of life, anxiety and depression in Turkish women prior to receiving assisted reproductive techniques. Int J Fertil Steril 2012: 6: 1-12.

3. Cwikel J, Gidron Y, Sheiner E. Psychological interactions with infertility among women. Eur J Obstet Gynecol Reprod Biol 2004, 117: 126-31.

4. Damti OB, Sarid O, Sheiner E, et al. Stress and distress in infertility among women. Harefuah 2008; 147: 256-60.

5. Drosdzol A, Skrzypulec V. Depression and anxiety among Polish infertile couples--an evaluative prevalence study. J Psychosom Obstet Gynaecol 2009; 30: 11-20.

6. Cousineau T, Domar A. Psychological impact of infertility. Best Pract Res Clin Obstet Gynaecol 2007; 21: 293-308.

7. Jafarzadeh-Kenarsari F, Ghahiri A, Zargham-Boroujeni A, Habibi M. Exploration of the counseling needs of infertile couples: A qualitative study. Iran J Nurs Midwifery Res 2015; 20: 552.

8. Hisli N. A study on validity and reliability test of the Beck Depression Scale. J Psychol 1988; 6: 118-22.

9. Beck AT, Epstein N, Brown G, Steer RA. An inventory for measuring clinical anxiety: psychometric properties. J Consult Clin Psychol 1988; 56: 893-7.

10. Ulusoy M, Sahin NH, Erkmen H. Turkish version of the beck anxiety inventory: psychometric properties. J Cogn Psychother 1998; 12: 163-72.

11.Farquhar , Rishworth JR, Brown J, Nelen WL, Marjoribanks J. Assisted reproductive technology: an overview of Cochrane Reviews. Cochrane Database Syst Rev 2015; 7: CD010537.

12. Unal S, Kargin M, Akyüz A. Factors that psychologically affect infertile women. TAF Prev Med Bull 2010; 9: 481-6.

13. Yassa M, Arslan E, Gulbahar DS. Effects of infertility treatment on anxiety and depression levels. Cukurova Med J 2019; 44: 410-5.

14. Yusuf L. Depression, anxiety and stress among female patients of infertility; a case control study. Pak J Med Sci 2016; 32: 1340-3.
15. Guerra D, Llobera A, Veiga A, Barri P. Psychiatric morbidity in couples attending a fertility service. Human Reprod 1998; 13: 1733-6.

16. Kushnir VA, Barad DH, Albertini DF, Darmon SK, Gleicher N. Systematic review of worldwide trends in assisted reproductive technology 2004-2013. Reprod Biol Endocrinol 2017; 15: 6.

17. Noorbala AA, Ramazanzadeh F, Malekafzali H, et al. Effects of a psychological intervention on depression in infertile couples. Int J Gynaecol Obstet 2008; 101: 248-52.

18. Milazzo A, Mnatzaganian G, Elshaug AG, Hemphill SA, Hiller JE, Astute Health Study Group. Depression and anxiety outcomes associated with failed assisted reproductive technologies: a systematic review and meta-analysis. PLoS One 2016; 11: e0165805.

19. Matthiesen SM, Frederiksen Y, Ingerslev HJ, Zachariae R. Stress, distress and outcome of assisted reproductive technology (ART): a meta-analysis. Hum. Reprod 2011; 26; 2763-76.

20. Purewal S, Chapman SCE, van den Akker OBA. A systematic review and meta-analysis of psychological predictors of successful assisted reproductive technologies. BMC Res Notes 2017; 10: 711.

21.Boivin J, Griffiths E, Venetis CA. Emotional distress in infertile women and failure of assisted reproductive technologies: metaanalysis of prospective psychosocial studies. BMJ 2011; 342: $\mathrm{d} 223$.

22. Purewal S, Chapman SCE, van den Akker OBA. Depression and state anxiety scores during assisted reproductive treatment are associated with outcome: a meta-analysis. Reprod Biomed Online 2018; 36: 646-57.

23. Gameiro S, Finnigan A. Long-term adjustment to unmet parenthood goals following ART: a systematic review and metaanalysis. Hum Reprod Update 2017; 23: 322-37.

24. Gameiro S, Boivin J, Dancet E, et al. ESHRE guideline: routine psychosocial care in infertility and medically assisted reproduction-a guide for fertility staff. Hum Reprod 2015; 11 : 2476-85

25. Bai CF, Cui NX, Xu X, et al. Effectiveness of two guided selfadministered interventions for psychological distress among women with infertility: a three-armed, randomized controlled trial. Hum Reprod 2019; 34: 1235-48.

26. Karaca A, Ünsal G. Stress level of infertile women due to infertility and effective factors. J Educ Res Nurs 2015; 12: 126-32.

27. Benli S. Depression And Anxiety Status and Associated Factors in Infertile Women. Master's Thesis. Selcuk University Institute of Health Sciences, Department of Nursing. 2010, Konya.

28. Karlidere T, Bozkurt A, Ozmenler KN, Ozsahin A, Kucuk T, Yetkin $\mathrm{S}$. The influence of emotional distress on the outcome of in-vitro fertilization (IVF) and/or intracytoplasmic sperm injection (ICSI) treatment among infertile Turkish women. Isr J Psychiatry Relat Sci 2008; 45: 55-64.

29. Gulseren L, Cetinay P, Tokatlioglu B, et al. Depression and anxiety levels in infertile Turkish women. J Reproduct Med 2006; 51: 421 6. 